\title{
Peningkatan Motivasi Belajar pada Pembelajaran Housekeeping melalui Layanan Konseling Kelompok
}

\author{
Putu Mariathi \\ SMK Negeri 2 Sukawati \\ e-mail: mariathi11@gmail.co.id
}

\begin{abstract}
Abstrak
Penelitian ini dilakukan berdasarkan permasalahan yaitu: 1) apakah pembelajaran dengan layanan Bimbingan dan Konseling kelompok berpengaruh terhadap peningkatan hasil belajar siswa ? dan 2) Seberapa besar peningkatan hasil belajar yang dicapai siswa setelah dilaksanakannya layanan Bimbingan dan Konseling secara kelompok ?. Tujuan dari penelitian ini adalah: 1) Untuk mengungkap pengaruh Pembelajaran dengan Layanan Bimbingan Dan Konseling kelompok terhadap hasil belajar siswa pada mata pelajaran housekeeping dan 2) Untuk mengetahui seberapa jauh pemahaman dan penguasaan siswa terhadap mata pelajaran housekeeping setelah diterapkannya Layanan Bimbingan dan Konseling secara kelompok. Penelitian ini menggunakan penelitian tindakan (action research) sebanyak dua putaran. Setiap putaran terdiri dari empat tahap yaitu: Rancangan, (Planning), Pelaksanaan Kegiatan dan pengamatan (Acting), Observasi (Observing) dan Refleksi / Tindakan (reflecting). Adapun hasil yang diperoleh melalui teknik pengumpulan data yaitu: observasi, tes dokumentasi dan wawancara, dijadikan acuan dalam menulis laporan penelitian Tindakan Kelas ini adalah: pada siklus I peningkatan hasil belajar siswa dengan nilai rata-rata 79,8 dan ketuntasan belajar mencapai $83,33 \%$ sedangkan pada siklus II peningkatan hasil belajar siswa dengan nilai rata-rata 83,53 dengan ketuntasan belajar mencapai $100 \%$. Kesimpulan dari Penelitian ini adalah dengan penerapan layanan Bimbingan dan Konseling Kelompok dapat meningkatkan hasil belajar siswa pada mata pelajaran housekeeping bagi siswa kelas $X$ Semester Satu Program Keahlian Akomudasi Perhotelan SMK Negeri 2 Sukawati tahun pelajaran 2016/2017 terbukti berhasil dengan baik".
\end{abstract}

Kata Kunci: Hasil Belajar Siswa, Pelajaran Houskeeping, Layanan Konseling Kelompok

\begin{abstract}
This research is based on the problems, namely: 1) what is learning with group guidance and counseling services that influence the improvement of student learning outcomes? And 2) how much increase in learning outcomes achieved by students after the implementation of guidance and counseling services in groups? The objectives of this study are: 1) To reveal the influence of Learning with Guidance Services and Group Counseling on student learning outcomes on housekeeping subjects, and 2) To reveal how far students understand and control the housekeeping subjects after the implementation of Guidance and Counseling Services in groups. This research uses two rounds of action research. Each round consists of four stages, namely: Planning, Activities and Acting, Observation, and Reflection. The results obtained through data collection techniques are: observation, documentation tests and interviews, used as a reference in writing this Classroom Action research report are: In the first cycle improvement in student learning outcomes with an average value of 79.8 and learning completeness reached $83.33 \%$ and In Cycle II improvement in student learning outcomes with an average value of 83.53 with learning completeness reaching $100 \%$. The conclusion of this study is that the application of the Guidance and Counseling Service group can improve student learning outcomes on housekeeping subjects for class $X$ students in the First Semester Program of Hospitality Expertise in SMK Negeri 2 Sukawati in the 2016/2017 academic year proved to be successful ".
\end{abstract}

Keywords: Improved Student Learning Outcomes, Houskeeping Lessons, Group Counseling Services 


\section{Pendahuluan}

Pariwisata merupakan salah satu sumber devisa negara selain dari sektor migas yang sangat potensial dan mempunyai andil besar dalam membangun perekonomian yang saat ini pertumbuhannya masih sangat lambat. Sektor pariwisata di Indonesia masih bisa untuk dikembangkan dengan lebih maksimal lagi. Pengembangan sektor pariwisata yang dilakukan dengan baik akan mampu menarik wisatawan domestik maupun wisatawan asing untuk datang dan berwisata di tempat tujuannya. Pariwisata Indonesia apabila mampu dikemas dan dikelola dengan baik akan menjadi aset negara Indonesia. Keberagaman objek wisata di Indonesia dapat mempengaruhi sektor-sektor industri pariwisata di Indonesia. Industri pariwisata sebenarnya dapat dijadikan salah satu penopang perekonomian negara dan juga dapat banyak menyerap tenaga kerja, sehingga sumber daya manusia dan sumber daya alam dapat dimanfaatkan secara optimal.

Menurut Rokhmi (2014) SDM merupakan salah satu unsur yang paling vital bagi organisasi. Tidak terkecuali bagi industri pariwisata sebagai sektor yang memiliki hubungan langsung secara intangible dengan konsumen sangat bergantung pada kemampuan dan keterampilan SDM Pariwisata. Menurut Mulya Sari (2015) Wisata Merupakan tujuan bagi seseorang untuk mengunjungi sesuatu yang mempunyai daya tarik baik berupa tempat benda atau alam yang bertujuan untuk memberikan rekreasi bagi diri seseorang. Menurut Prasetya (2014) pariwisata adalah suatu aktivitas yang kompleks, yang dapat dipandang sebagai suatu system yang besar, yang mempunyai berbagai komponen seperti ekonomi, politik, social, budaya, dan seterusnya. Pariwisata menjadi salah satu primadona bagi negara-negara dalam meningkatkan sumber pendapatannya diluar dari migas dan pajak. Saat ini Indonesia sebagai salah satu negara berkembang mulai mempromosikan negaranya guna menarik pandangan mata dunia lain, hal ini dimaksudkan agar Indonesia semakin terkenal bagi warga/penduduk negara lain untuk berkunjung ke Indonesia. Promosi-promosi yang dilakukan adalah menjual keragaman wisata dan budaya Indonesia, hal inilah ditanggapi positif dengan banyaknya wisatawan dari mancanegara yang berkunjung ke Indonesia. Menurut Lastariwati (2012) Pembelajaran merupakan suatu proses yang berlangsung seumur hidup, yaitu pembelajaran sejak lahir hingga akhir hayat yang diselenggarakan secara terbuka dan multi makna. Pembelajaran seumur hidup berlangsung secara terbuka melalui jalur: formal, non formal, serta informal yang dapat diakses oleh peserta didik setiap saat tanpa dibatasi usia, tempat, dan waktu. Terkait dengan pendidikan multi makna diselenggarakan dengan berorientasi pada pembudayaan, pemberdayaan, pembentukan akhlak mulia, budi pekerti luhur dan watak kepribadian, atau karakter yang unggul serta berbagai kecakapan hidup (life skills). Penguatan pendidikan kejuruan dibidang Pariwisata merupakan salah satu hal yang diprioritaskan pemerintahan. Dimana, pendidikan kejuruan dipercaya mampu menghasilkan tenaga kerja yang terdidik dan terampil, sehingga berdampak pada pertumbuhan ekonomi yang signifikan. Sekolah Menengah Kejuruan (SMK) yang mengembangkan Program Studi Perhotelan memiliki peranan penting dalam memajukan perekonomian bangsa oleh karena itu siswa yang memilih program studi perhotelan sangat mendominasi jumlahnya dibandingkan dengan program studi lainnya yang dikembangkan di SMK Saat ini. Menurut Samsudi (2014) pada proses penyelenggaraan pembelajaran di SMK dikenal adanya pembelajaran program produktif. Pembelajaran ini berisi sekumpulan mata pelajaran (diklat) yang secara spesifik bertujuan membekali peserta didik agar memiliki kompetensi produktif melalui pembelajaran praktik di sekolah dan/atau di dunia usaha/industri, sesuai dengan Standar Kompetensi Kerja Nasional Indonesia (SKKNI).

SMK Negeri 2 Sukawati mengembangkan program keahlian Akomudasi Perhotelan dengan kompetensi keahlian yang relevan dengan kebutuhan dunia kerja merupakan salah satu bagian dari implementasi kebijakan Pemerintah dalam upaya memenuhi tenaga kerja tingkat menengah dibidang Pariwisata. Disisi lain hotel dapat menyerap banyak tenaga kerja yang berdampak akan dapat mengurangi angka pengangguran. Oleh karena itu tamatan dari Program keahlian Akomudasi Perhotelan harus betul-betul disiapkan dengan seoptimal mungkin agar mutu tamatannya dapat diserap di dunia kerja dibidang perhotelan dengan baik. Salah satu upaya yang dilakukan oleh Sekolah adalah meningkatkan motivasi belajar bagi siswa agar tetap berkomitmen pada diri siswa tersebut untuk mengikuti pembelajaran disekolah dengan baik dan disiplin. Selain itu pembelajaran pada Program Keahlian Akomudasi Perhotelan memerlukan tingkat kedisiplinan yang sangat tinggi agar setelah terjun ke dunia kerja siswa mampu beradaptasi dengan dunia kerja secara cepat. Perhotelan memiliki bagian- 
bagian operasional yang menunjang berjalannya kegiatan perhotelan dengan baik. Salah satu dari bagian tersebut adalah Housekeeping.

Upaya dalam meningkatkan motivasi siswa dalam mengikuti pembelajaran di kelas merupakan tolok ukur untuk mencapai tujuan yang diinginkan (dicita-citakan) oleh lembaga, orang tua dan siswa. Ini perlu ditunjang dengan pemahaman siswa terhadap konsep diri tentang motivasi. Berdasarkan dari pengamatan yang telah dilakukan terhadap hasil belajar siswa kelas X Semester Satu Program Studi Akomudasi Perhotelan SMK Negeri 2 Sukawati rata-rata rendah hanya mencapai $53,33 \%$. Hal perlu dilakukan upaya pemecahannya agar motivasi belajar dalam mengikuti pembelajaran housekeeping dapat mencapai tingkat yang lebih baik.

Melalui Penelitian Tindakan Kelas ini Peneliti berupaya mencari solusi terhadap masalah yang ada di lingkungan siswa kelas $X$ Semester Satu Program Keahlian Akomudasi perhotelan SMK Negeri 2 Sukawati mengenai motivasi siswa dalam mengikuti pembelajaran housekeeping yang rendah tersebut. Berdasarkan penjelasan diatas, maka peneliti mengambil judul dalam Penelitian Tindakan Kelas ini adalah "Peningkatan Motivasi Belajar Pada pembelajaran Housekeeping melalui layanan Konseling kelompok Bagi Siswa Kelas X Semester Satu Program Keahlian Akomudasi Perhotelan SMK Negeri 2 Sukawati Tahun Pelajaran 2016/2017".

\section{Metode}

Waktu Penelitian mulai dari Perencanaan sampai dengan penulisan laporan hasil penelitian tersebut mulai dari bulan Juli s.d Desember 2016, pada semester satu tahun pelajaran 2016/2017. Subjek Penelitian ini adalah siswa kelas X. Semester Satu program keahlian akomudasi Perhotelan yang berjumlah 30 orang. Adapun objek dalam penelitian ini adalah peningkatan motivasi belajar pada pembelajaran Housekeeping melalui layanan Konseling.

Penelitian Tindakan Kelas ini target Penelitian telah tercapai sesuai dengan rencana. Adapun bagan dari prosedur Penelitian ini dapat disampaikan sebagai berikut:

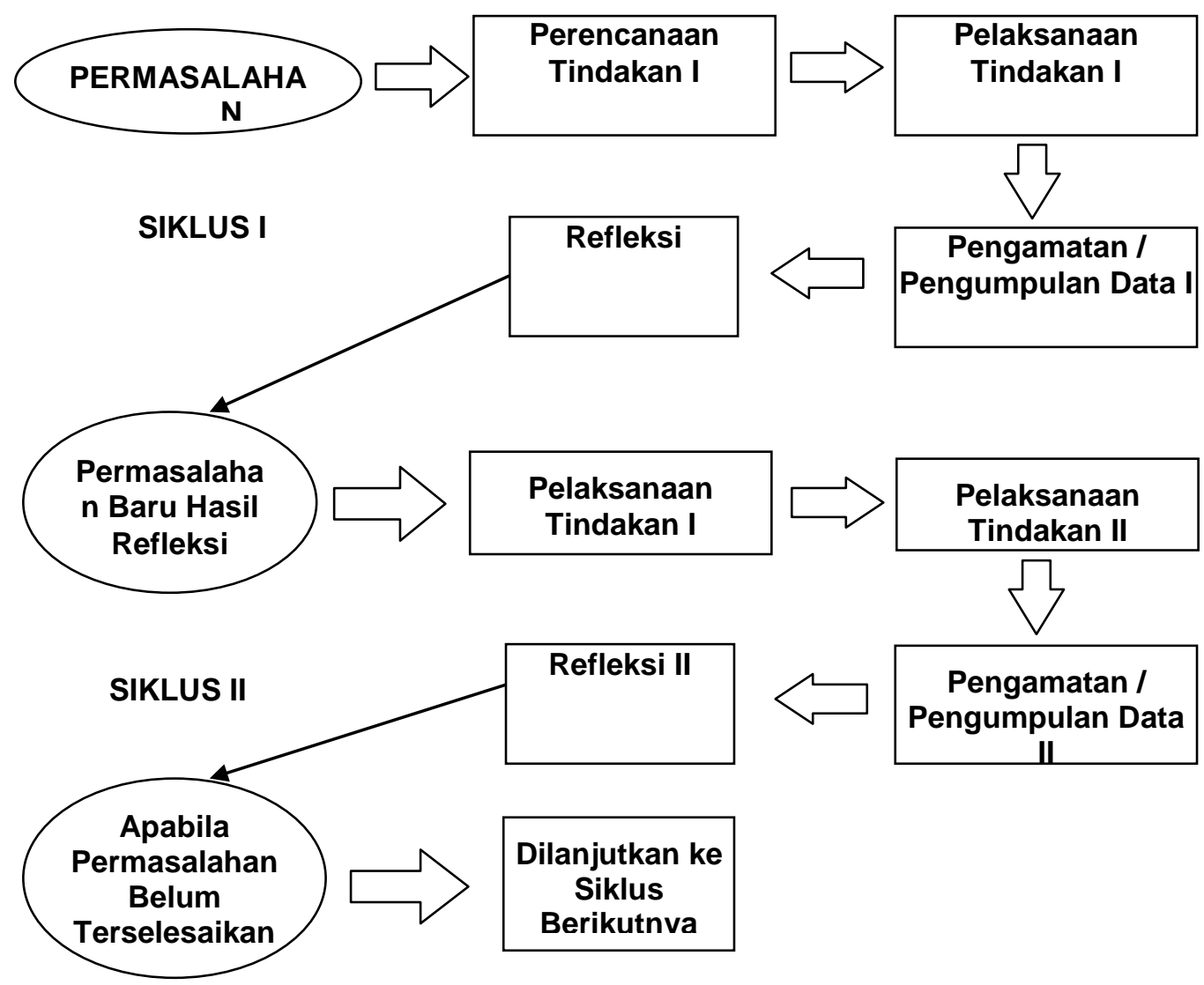

(Suhardjono, 2006 :

Gambar 1. prosedur Penelitian 
Tahapan pada gambar siklus alur prosedur Penelitian Tindakan Kelas yang di paparkan diatas dapat dijelaskan sebagai berikut:

1. Siklus I

a. Perencanaan

Pada tahapan ini peneliti / guru membuat rancangan tentang fokus permasalahan yang perlu mendapatkan perhatian yaitu:

1) Menyusun kelengkapan administrasi guru termasuk program layanan Konseling kelompok dan lainnya,

2) Menyiapkan instrumen penelitian untuk guru dan siswa,

3) Menyiapkan format evaluasi pretest dan postest,

4) Menyiapkan sumber yang relevan dengan layanan Bimbingan dan Konseling kelompok yang di berikan kepada siswa.

5) Menyiapkan strategi pelaksanaan layanan Bimbingan dan Konseling serta melakukan koordinasi dengan guru mata pelajaran yang terkait dengan Penelitian ini, demikian juga guru mata paelajaran lainnya sebagai kolaburator / observer.

6) Guru mata pelajaran penyiapan bahan dan pengembangan skenario pembelajaran dan guru BK melakukan Bimbingan dan Konseling kelompok kepada siswa untuk memberikan motivasi agar hasil belajar housekeeping dapat ditingkatkan ke tingkat yang lebih baik.

b. Pelaksanaan

1)Guru mata pelajaran melaksanakan apersepsi, motivasi untuk mengarahkan siswa dapat meningkatkan motivasi dalam mengikuti pembelajaran housekeeping melalui layanan Bimbingan Konseling kelompok secara bergantian terpadu dan berkolaborasi dengan baik dalam bentuk team teaching,

2)Guru menjelaskan tujuan pembelajaran dan bimbingan yang akan dicapai,

3) Guru menjelaskan materi yang perlu dipahami siswa pada hari itu dan menjelaskan langkah-langkah kerja dalam belajar siswa diminta mengikutinya dengan baik serta mengoptimalkan layanan bimbingan dan konseling kelompok untuk meningkatkan motivasi dalam mengikuti pembelajaran housekeeping.

4)Guru mendiskusikan kembali dengan seluruh siswa, bila perlu mengadakan inovasi pembelajaran dalam strategi dan variasi kelompok, sedangkan guru BK menuntun siswa jika terdapat masalah pada siswa.

5)Guru mengadakan tes atau ulangan.

c. Pengamatan

1)Observasi (kolaborasi) mengamati kegiatan guru pada saat pembelajaran dan mengamati kegiatan siswa dengan menggunakan instrument pengamatan pembelajaran guru dan siswa,

2)Guru mengevaluasi kegiatannya dengan menggunakan angket guru.

d. Refleksi

Hasil evaluasi direfleksikan untuk tindakan selanjutnya dengan pembahasan pada hasil observasi, Kekurangan yang terjadi pada siklus I dikaji lebih lanjut dan diperbaiki pada siklus II akan dilaksanakan langkah-langkah yang sama seperti yang dilakukan pada siklus I, namun pelaksanaannya lebih dimantapkan pada komponen-komponen yang belum mencapai hasil maksimal. Sehingga melalui perbaikan tersebut hasilnya akan lebih sempurna.

2. Siklus II

Pada siklus II guru bersama dengan Peneliti melakukan tindakan atau refleksi bagi siswa yang tingkat motivasi belajarnya rendah. Kegiatan yang dilakukan pada siklus II sama dengan yang dilakukan pada siklus I ( seperti yang telah dijelaskan diatas). Melalui penerapan layanan Bimbingan dan Konseling kelompok ini diharapkan dapat meningkatkan motivasi siswa dalam pembelajaran sehingga mampu menuntaskan pembelajaran yang diikutinya. Hasil yang dicapai pada siklus II adalah hasil akhir dari proses Penelitian Tindakan Kelas ini. pada siklus II di harapkan semua siswa telah berhasil meningkatkan hasil belajarnya dengan baik. 


\section{Hasil dan Pembahasan}

Penerapan layanan Bimbingan dan Konseling kelompok dalam meningkatkan motivasi siswa telah terbukti dapat meningkatkan hasil belajar siswa kelas $\mathrm{X}$ Semester satu program keahlian akomudasi perhotelelan di SMK Negeri 2 Sukawati Tahun Pelajaran 2016/2017. Kegiatan yang sudah dilakukan yang terdiri dari empat langkah yaitu: perencanaan, tindakan, observasi dan refleksi terlaksana dengan konsisten. Keempat langkah tersebut berlangsung secara berulang-ulang melalui dua siklus dan pada setiap siklus diadakan identivikasi, refleksi, dan evaluasi untuk mengetahui peningkatan serta kemajuan yang dicapai oleh siswa. Hasil Penelitian yang dimulai dari pra sklus ke siklus I mengalami perbedaan, kemudian dari siklus I, ke siklus II mengalami peningkatan dan perbedaan. Perbedaan tersebut terjadi memang tujuannya adalah untuk mencapai peningkatan motivasi siswa melalui layanan konseling kelompok yang dicapai oleh siswa sebagai wujud hasil pembelajaran.

Diharapkan memberikan manfaat banyak bagi siswa dalam membentuk pribadi yang berkualitas. Dari hasil pengamatan pun dapat dilihat perubahan terhadap motivasi siswa dan siswa nampak lebih aktif serta lebih percaya diri mandiri dalam refleksi.

Adapun hasil yang dapat disajikan dalam pembahasan ini dimulai dari prasiklus, siklus I, Siklus II dalam bentuk rekapitulasi sebagai beikut :

Tabel 1. Rekapitulasi Hasil Penelitian Tindakan Kelas

\begin{tabular}{clcccl}
\hline \multirow{2}{*}{ No. } & \multirow{2}{*}{ Kriteria } & \multicolumn{3}{c}{ Jenis Tindakan } & \multirow{2}{*}{ Ket. } \\
\cline { 3 - 5 } & & $\begin{array}{c}\text { Pre test } / \\
\text { Prasiklus }\end{array}$ & S.I & S.II & \\
\hline 1. & Jumlah Nilai & 2201 & 2397 & 2506 & Meningkat \\
2. & Rata-rata Nilai & 73,36 & 79,8 & 83,53 & Meningkat \\
3. & Ketuntasan Belajar & $53,33 \%$ & $83,33 \%$ & $100 \%$ & Meningkat \\
4 & Siswa yg Belum Tuntas & $46,67 \%$ & $16,6 \%$ & $0 \%$ & \\
\hline
\end{tabular}

Keberhasilan tindakan yang dilakukan peneliti telah terbukti bahwa dengan menerapkan Bimbingan dan Konseling kelompok mampu meningkatkan motivasi siswa kelas $X$ Semester satu Program keahlian akomudasi perhotelan SMK Negeri 2 Sukawati Tahun Pelajaran 2016/2017, dengan baik dan sesuai dengan rancangan yang telah dilakukan pada Penelitian Tindakan Kelas ini.

Dari hasil rekapitulasi tersebut diatas nampak perkembangan peningkatan yang dicapai siswa mulai dari Pra Siklus, Siklus I, dan Siklus II, setelah dilakukan tindakan dan refleksi di setiap siklus. Peningkatan tersebut terjadi secara signifikan. Keberhasilan penerapan Bimbingan dan Konseling kelompok untuk meningkatkan motivasi siswa kelas X Semester satu program keahlian akomudasi perhotelan SMK Negeri 2 Sukawati tercapai dengan baik pada tahun pelajaran 2016/2017. Dari jumlah 30 orang siswa pada siklus II yang diteliti dengan tindakan kelas melalui penerapan Bimbingan dan Konseling kelompok, sebanyak 100\% siswa berhasil meningkatkan motivasi dalam belajar housekeeping pada program keahlian akomudasi perhotelan SMK Negeri 2 Sukawati. Dengan demikian tindakan pada siklus kedua ini sudah dianggap berhasil dengan baik.

Temuan pada penelitian ini sejalan dengan hasil penelitian yang dilakukan oleh Fiah dan Ice (2016) yang berjudul Efekitvitas Layanan Konseling Kelompok dengan Pendekatan Realita untuk Mengatasi Kesulitan Komunikasi Interpersonal Peserta Didik Kelas X Man Krui Lampung Barat T.P 2015/2016. Pada penelitiannya dinyatakan bahwa: hasil perhitungan Zhitung $=2,803>$ Ztabel $=1,96$ dari signifikan $0,05 \%$ dan derajat kebebasan $(\mathrm{db}=\mathrm{n}-2=10-$ $2=8$ ). Dengan demikian penelitian ini yang menyimpulkan bahwa hipotesis yang menyatakan "Layanan Konseling Kelompok dengan Pendekatan Realita Efektif untuk Mengatasi Kesulitan Komunikasi Interpersonal Peserta Didik Kelas X MAN Krui Lampung Barat tahun ajaran 2015/2016", terbukti kebenarannya.

\section{Kesimpulan}

Berdasarkan hasil Penelitian Tindakan Kelas ( PTK), dapat ditarik kesimpulan sebagai berikut: 1) Penerapan Bimbingnan dan Konseling secara kelompok dapat meningkatkan motivasi dalam belajar housekeeping bagi siswa kelas X Semester satu SMK Negeri 2 Sukawati Tahun pelajaran $2016 / 2017$, 2) Kemampuan siswa dalam meningkatkan motivasinya untuk 
mengikuti pembelajaran housekeeping melalui layanan bimbingan dan konseling kelompok dapat memberi manfaat untuk meningkatkan motivasi siswa dalam belajar, 3) Hasil Penelitian dari prasiklus, siklus I dan siklus II mengalami peningkatan , dan 4) Motivasi akan senantiasa menentukan usaha belajar bagi para siswa. Siswa yang mempunyai motivasi belajar maka akan berusaha menyelesaikan tugasnya, tidak cepat putus asa, memiliki minat belajar yang tinggi, senang dengan tugas-tugas yang menantang, dan bila memiliki keyakinan bahwa sesuatu itu benar maka berusaha mempertahankan pendapatnya.

Telah terbuktinya bahwa penerapan Bimbingan dan Konseling secara kelompok dapat meningkatkan motivasi belajar siswa kelas X Semester Satu Program keahlian Akomudasi Perhotelan SMK Negeri 2 Sukawati tahun pelajaran 2016/2017. Untuk itu Peneliti mencoba memberikan saran sebagai berikut : 1) Dalam upaya meningkatkan motivasi belajar siswa pada mata pelajaran housekeeping pemberian layanan Bimbingan dan Konseling secara kelompok sangat tepat. pihak sekolah dapat mengalokasikan waktu yang cukup dalam menerapkan Bimbingandan Konseling bagi siswa, 2) Kesinambungan kegiatan Bimbingan dan Konseling secara kelompok dapat dipertahankan karena banyak manfaat bagi siswa dalam meningkatkan motivasi belajar siswa, 3) Guru Bimbingan Konseling berupaya mengembangkan metode yang tepat dalam memberikan layanan konseling bagi siswa di SMK Negeri 2 Sukawati, 4) Pelayanan Bimbingan dan Konseling di sekolah disamping meningkatkan motivasi belajar siswa diharapkan juga dapat membentuk karakter siswa, dan 5) Permasalahan yang terjadi pada siswa sangat kompleks, untuk itu penanganan masalah tersebut harus diatasi bersama agar tuntas semua permasalahan, peran serta guru BK sangatlah penting dalam hal ini.

\section{Daftar Pustaka}

Abdurrahman dan Bintoro. 2000. Memahami dan menangani Siswa dengan Problema Belajar. Jakarta; Depdiknas.

Amos Kandola. 2006. Model-model Pembelajaran Matematika di Sekolah. Jakarta: UNJ.

Aqib Zainal. 2004. Profesional Guru Dalam Pembelajaran. Surabaya; Insan Cindikia.

Arikunto, Suharsimi. 1992. Prosedur Penelitian Suatu Pendekatan Praktik. Jakarta: Rineka Cipta.

Fiah dan Ice. 2016. Efekitvitas Layanan Konseling Kelompok Dengan Pendekatan Realita Untuk Mengatasi Kesulitan Komunikasi Interpersonal Peserta Didik Kelas X Man Krui Lampung Barat T.P 2015/2016. Jurnal Bimbingan dan Konseling 03 (1) (2016) 47-62, pISSN 2089-9955, e-ISSN 2355-8539.

Lastariwati, Badraningsih. 2012. Pentingnya Kelas Kewirausahaan Pada SMK Pariwisata. Jurnal Pendidikan Vokasi Vol 2 No. 1 Hal. 71-80. https://journal.uny.ac.id/index.php. Diakses 17 Mei 2019.

Majid, Abdul. 2006. Perencanaan Pembelajaran, Mengembangkan standar Kompetensi Guru. Bandung: PT. Remaja Rosdakarya.

Mulya Sari, Deasy. 2015. Partisipasi Masyarakat dalam Mengembangkan sarana Prasarana Kawasan Desa Wisata Borobudur. Modul Vol. 15 No. 2. https://ejournal.undip.ac.id/index.php/modul/article/download/10772/8546. Diakses 17 Mei 2019.

Prasetya Maha Rani, Deddy. 2014. PENGEMBANGAN POTENSI PARIWISATA Kabupaten Sumenep, Madura, Jawa Timur (Studi Kasus: Pantai Lombang). Jurnal Politik Muda Vol. 3 No. 3 Hal. 412-421. http://journal.unair.ac.id/download-fullpapersjpm5b0b20ff16full.pdf. Diakses 17 Mei 2019.

Renita Mulyaningtyas, Yus Purnomo Hadiyanto. 2006. Bimbingan dan Konseling SMA Kelas X. Tesis. Jakarta. 
Rokhmi Lestari, Siti. 2014. Manajemen Pengembangan Dosen sebagai Upaya Meningkatkan Mutu Sekolah Tnggi Pariwisata AMPTA Yogyakarta. Jurnal Media Wisata, Vol. 12 No. 2. http://www.amptajurnal.ac.id/index.php/. Diakses 17 Mei 2019.

Samsudi. 2014. Pengembangan Model Pembelajaran Program Produktif SMK untuk Membentuk Karakter Kewirausahaan Lulusan. Cakrawala Pendidikan No. 2. https://journal.uny.ac.id/index.php/cp/article/view/2170. Diakses 17 Mei 2019.

Sanjaya, W, 2006. Strategi Pembelajaran. Jakarta: Kencana Prenada Media Group.

Syarifuddin Dahlan. 2014. Bimbingan dan Konseling di sekolah, Konsep Dasar Landasan Pelayanan. Bandar Lampung; Graha IImu. 